\title{
PERAN RELIGIUSITAS DAN BATASAN WAKTU AUDIT TERHADAP EFEKTIVITAS FUNGSI INTERNAL AUDIT DI BMT KARISMA MAGELANG
}

\author{
Yulida Army Nurcahya \\ Universitas Tidar \\ yulidaarmy@untidar.ac.id \\ Ema Ismawati \\ Universitas Tidar \\ emais0410@gmail.com \\ Risma Wira Bharata \\ Universitas Tidar \\ rismawirab@untidar.ac.id
}

\begin{abstract}
Abstrak: Peran Religiusitas Dan Batasan Waktu Audit Terhadap Efektivitas Fungsi Internal Audit Di BMT Karisma Magelang Penelitian ini bertujuan untuk mengetahui peran religiusitas dan batasan waktu audit terhadap efektivitas fungsi audit internal di Baitul Mal Wa Tamwil (BMT) Karisma, Magelang. Terlibatnya sifat religiusitas pada sumber daya manusia di lembaga keuangan syariah, dan adanya batasan waktu yang berlaku dapat mempengaruhi efektivitas fungsi audit. Penelitian ini menggunakan metode kualitatif dengan menggunakan teknik wawancara untuk pengumpulan data. Narasumber dalam penelitian ini adalah 2 orang auditor internal yang telah menjalani profesi audit internal di BMT Karisma, Magelang. Hasil penelitian ini menunjukkan Religiusitas individu akan meningkatkan integritas dan independensi auditor yang kemudian dapat mencapai keefektifan fungsi audit internal. Adanya religiusitas di setiap individu akan mewujudkan kinerja yang penuh kehati hatian, ketelitian, ketekunan dan terhindar dari kecurangan. Dengan terwujudnya efektivitas fungsi audit internal melalui faktor religiusitas akan menghasilkan laporan audit yang berkualitas dan dapat dipercaya, serta menjadi langkah untuk memajukan lembaga keuangan syariah. Batasan waktu sejalan dengan tingkat efektivitas fungsi audit internal. Auditor perlu menjalankan manajemen waktu di atas batasan waktu yang telah ditentukan. Sehingga, auditor dapat menuntaskan tugasnya, dan memenuhi fungsi auditor secara efektif.
\end{abstract}

Kata kunci: Religiusitas, Batasan Waktu Audit, Efektivitas Fungsi Audit

\begin{abstract}
The Role of Religiousity and Audit Time Limitaton on Internal Audit Function in BMT Karisma Magelang This study aims to determine the role of religiosity and audit time limits on the effectiveness of the internal audit function in the Baitul Mal Wa Tamwil (BMT) Karisma, Magelang. The involvement of religiosity in human resources in Islamic financial institutions, and the existence of time limits that can affect the effectiveness of the audit function. This study uses a qualitative method using interview techniques for data collection. The resource persons in this study were 2 internal auditors who had undertaken the internal audit profession at BMT Karisma, Magelang. The results of this study indicate that individual religiosity will increase the integrity and independence of auditors who can then achieve the effectiveness of the internal audit function. The existence of religiosity in each individual will create performance that is full of prudence, accuracy, perseverance and avoiding fraud. With the realization of the effectiveness of the internal audit function through the factor of religiosity will produce a quality audit report that can be trusted, as well as a step to advance Islamic financial institutions.and the time limit is in line with the effectiveness of the internal audit function. The auditor needs to run time management above the specified time limit. Thus, the auditor can complete his duties, and fulfill the auditor's function effectively.
\end{abstract}

Keywords: Religiosity, Audit Time Limits, Audit Function Effectiveness 


\section{PENDAHULUAN}

Lembaga keuangan syariah merupakan sektor yang sangat potensial dalam menciptakan kesejahteraan di Indonesia. Indonesia merupakan sebuah negara yang di dalamnya berkembang lembaga keuangan baik konvensional maupun syariah. Sensus penduduk tahun 2010 mendapatkan data bahwa jumlah penduduk Indonesia mencapai lebih dari dua ratus juta jiwa dengan jumlah penduduk muslim lebih dari setengahnya.

Unit - unit usaha syariah terus bermunculan seiring dengan berkembangnya perbankan syariah. Termasuk BMT (Baitul Maal Wa Tamwil) yang merupakan salah satu Lembaga Keuangan Mikro Syariah (LKMS), yang terus berkembang di setiap daerah. BMT berdiri dengan menjalankan syariah islam dalam operasionalnya. Potensi BMT yang semakin berkembang pesat, selain kinerja BMT yang menjadi perhatian, tidak lupa jati diri yang paling pokok dari BMT adalah identitas keislamannya (Hendriani, 2012).

Untuk mencapai tujuan yang dimiliki BMT maka faktor terpenting yang dibutuhkan adalah sumber daya manusia. Keberadaan sumber daya manusia memegang peranan penting dalam menjalankan kegiatan operasional. Tidak sekedar adanya sumber daya manusia, namun kualitas sumber daya manusia tersebut yang sangat mempengaruhi tumbuh kembangnya sebuah lembaga keuangan. Meskipun terdapat fasilitas dan teknologi yang memadai, tanpa sumber daya manusia yang berkualitas maka tidak akan menjamin hasil dengan maksimal.

Sumber daya manusia yang terlibat di lembaga keuangan syariah tidak terlepas dari sikap religiusitas. Sikap religiusitas yang dimiliki setiap individu akan menjadi hal penting dalam pelaksanaan kerja dan sebagai pembatas dalam persaingan dunia ekonomi.

Religiusitas seakan akan mendorong individu untuk lebih berhati - hati dan bijak dalam bekerja. Ketakutan atas ancaman dan keyakinan manusia untuk senantiasa bersikap baik, dengan menaati perintah dan menjauhi larangan Allah SWT dengan sungguh - sungguh dan penuh keiklasan (Setiawati, 2019). Dengan bekal religiusitas membuat individu semakin teliti dan hati hati hingga kemudian dapat menuntaskan fungsi auditor dengan baik.

Lembaga keuangan syariah secara konseptual dilaksanakan dengan maksud untuk menghindari riba. Kegiatan menghindari riba tersebut dilaksanakan melalui praktik dan inovasi berasarkan syariat islam. Selain itu, dengan didirikannya lembaga keuangan syariah diharapkan dapat membangun budaya baru dalam pengelolaan lembaga keuangan. 
Dewan Pengawas Syariah (DPS) adalah dewan yang melakukan pengawasan terhadap prinsip syariah dalam kegiatan usaha bank syariah yang dalam menjalankan fungsinya bertindak secara independen (Muhammad, 2011). Untuk mewujudkan prinsip - prinsip syariah yang baik maka penting adanya peran dari Dewan Pengawas Syariah (DPS). Untuk melakukan pengawasan, anggota harus memiliki integritas dan independen. Independensi adalah sikap seseorang dimana dalam sudut pandang, pendapat, maupun kesimpulan yang disampaikannya tidak bergantung pada pengaruh dan tekanan dari pihak yang berkepenringan (Kasim,At.al, 2013). Tak hanya itu, anggota juga harus berkompeten mengenai ilmu fiqh muamalah dan ilmu ekonomi syariah modern.

BMT memiliki Dewan Pengawas Syariah merupakan Peraturan Meneg Koperasi dan UKM RI No.35.2/PER/M.KUKM/X/2007 Tentang Pedoman Standar Operasional Manajemen KJKS dan UJKS Koperasi, dalam BAB I Ketentuan Umum, pasal 1 ayat 8 menyebutkan :

"Dewan Pengawas Syariah pada KJKS dan UJKS Koperasi adalah dewan yang dipilih oleh koperasi yang bersangkutan berdasarkan keputusan rapat anggota dan beranggotakan alim ulama yang ahli dalam syariah yang menjalankan fungsi dan tugas sebagai pengawas syariah pada koperasi yang bersangkutan dan berwenang memberikan tanggapan atau penafsiran terhadap fatwa yang dikeluarkan Dewan Syariah Nasional"

Di sisi lain dalam sebuah lembaga keuangan sangat dibutuhkan pengendalian internal termasuk di dalamnya audit internal. Semakin berkembangnya lembaga keuangan semakin berkembang pula fungsi audit internal. Ada beberapa faktor yang mempengaruhi kualitas audit, yaitu hal yang sering menjadi perhatian tim audit adalah faktor keterbatasan waktu yang dialokasikan oleh entitas audit kepada tim dalam melaksanakan tugasnya. Sehingga dengan alokasi waktu yang terbatas dapat berimbas pada keakuratan dalam penyajian laporan audit. Hampir dari sejumlah penugasan yang ditangani oleh auditor rata-rata dapat menambah tingkat tekanan waktu yang dirasakan yang pada akhirnya dapat berdampak pada kualitas audit (Svanstrom, 2016). Begitu pula dengan audit internal dalam sebuah entitas. Faktor batasan waktu sangat mempengaruhi kinerja dan penerapan fungsinya hingga pada akhirnya berimbas pada kualitas laporan audit.

Efekfitas fungsi audit internal diukur dari kemampuan auditor internal untuk menyajikan temuan dan rekomendasi yang ditindaklanjuti oleh pihak manajemen (Mihret, et.al, 2007). Berdasarkan uraian di 


\section{Nominal: Barometer Riset Akuntansi dan Manajemen}

P-ISSN: 2303-2065 E-ISSN: 2502-5430

Volume 9 No 1 (2020)

atas, maka penelitian ini mengajukan pertanyaan penelitian sebagai berikut bagaimana peran religiusitas dan batasan waktu audit terhadap efektifitas fungsi audit internal di BMT Karisma Magelang.

\section{KAJIAN LITERATUR}

Religiusitas merupakan suatu sikap atau kesadaran yang muncul yang didasarkan atas keyakinan atau kepercayaan seseorang terhadap suatu agama (Sahlan, 2012). Religiusitas adalah tingkah laku manusia yang sepenuhnya dibentuk oleh kepercayaan kepada kegaiban atau alam gaib, yaitu kenyataan-kenyataan supra-empiris. Manusia melakukan tindakan empiris sebagaimana layaknya tetapi manusia yang memiliki religiusitas meletakan harga dan makna tindakan empirisnya dibawah supraempiris (Madjid,1992). Nilai - nilai Islam seharusnya menjadi bagian pranata keislaman, sehingga ikut menentukan sikap seseorang dalam mengantisipasi dan memecahkan setiap persoalan yang dihadapinya (Madjid, 1997). Menurut Pamungkas (2014) Hubungan konseptual antara religiusitas dengan kualitas audit dijelaskan bahwa, tingkat religiusitas yang semakin tinggi akan menurunkan tingkat rasionalisasi seseorang dikarenakan sudah terbiasa melakukan penghayatan terhadap ajaran agama dikehidupan sehari - hari. Sebelum seseorang melakukan suatu tindakan yang mengarah kriminalitas maupun kecurangan akuntansi maka seseorang akan melalui dilemma kognitif dan menurunkan atau menaikkan pembenaran atau tingkat rasionalisasi. Jika tingkat rasionalisasi seseorang yang semakin rendah maka. Kecenderungan kecurangan akuntansi juga akan semakin menurun.

Batasan waktu audit merupakan batasan waktu yang diberikan kepada auditor dalam melakukan pemeriksaan terhadap suatu instansi atau perusahaan (Maulina, et.al, 2017). Dalam SPAP (SA Seksi 326, PSA No 07) disebutkan bahwa auditor bekerja dalam batas - batas pertimbangan ekonomi agar secara ekonomis bermanfaat, pendapatnya harus dirumuskan dalam jangka waktu yang masuk akal. Hastuti, (2013) mengungkapkan bahwa tekanan anggaran waktu yang dirasakan berhubungan positif signifikan dengan perilaku audit disfungsional, yang mengindikasikan semakin tinggi tekanan anggaran waktu yang dirasakan auditor, maka semakin meningkat pula kecenderungan mereka melakukan tindakan audit disfungsional, yaitu perilaku penurunan kualitas audit dalam pelaksanaan program audit. Sumartono, et.al, (2019) mengungkapkan di bawah tekanan - tekanan waktu, perhatian akan lebih terfokus pada tugas yang dominan seperti tugas pengumpulan bukti berkaitan dengan frekuensi dan jumlah salah saji dan 


\section{Nominal: Barometer Riset Akuntansi dan Manajemen}

P-ISSN: 2303-2065 E-ISSN: 2502-5430

Volume 9 No 1 (2020)

mengorbankan perhatian yang diberikan pada tugas tambahan seperti tugas yang memberikan aspek kualitatif atas terjadinya salah saji yang menunjukkan potensial kecurangan pelaporan keuangan. Lain halnya dengan Rustiarini, (2013) yang mengungkapkan bahwa tekanan waktu tidak berpengaruh pada kinerja auditor, dimana auditor semestinya dituntut untuk dapat bekerja seefesien mungkin sesuai anggaran waktu yang ditentukan.

Audit internal adalah fungsi penilaian independen yang didirikan dalam suatu organisasi untuk memeriksa dan mengevaluasi kegiatannya sebagai layanan bagi organisasi (Moeller, et.al, 2005). Fungsi audit internal yang efektif adalah yang dapat mencapai tujuannya, dan misi sebenarnya dari departemen audit internal adalah untuk membantu meningkatkan keadaan pengendalian internal di perusahaan (Cangemy, et.al, 2003). Efektivitas fungsi audit internal dipengaruhi oleh : (1) Kualitas audit internal, yaitu : keahlian staf, lingkup pelayanan, perencanaan audit, pengamatan dan pengendalian serta komunikasi yang efektif; (2) Dukungan manajemen, yaitu : tanggapan temuan audit dan komitmen untuk memperkuat audit internal; (3) Pengaturan organisasi, yaitu : profil organisasi, organisasi internal, kebijakan dan prosedur dan anggaran departemen audit internal; (4) Kebijakan dan prosedur pada auditan, yaitu : keahlian auditan, sikap auditan terhadap audit internal dan kerjasama auditan terhadap audit internal (Mihret, et.al, 2007). Audit internal yang efektif memiliki 4 komponen utama: 1. Verivikasi/ pengujian terhadap catatan, 2. Analisis Kebijakan, 3. Evaluasi atas prosedur secara logis dan lengkap, 4. Melaporkan rekomendasi untuk perbaikan bagi manajemen (Eden dan Moriah, 1996)

\section{METODE PENELITIAN}

Objek penelitian adalah BMT Karisma, Magelang. Pendekatan yang peneliti gunakan adalah pendekatan kualitatif. Penelitian kualitatif lebih menekankan analisisnya pada proses penyimpulan deduktif dan induktif serta pada analisis terhadap dinamika hubungan antar fenomena yang diamati, dengan menggunakan logika ilmiah (Wirartha, 2006). Penulis memilih menggunakan pendekatan kualitatif karena penelitian ini tidak menyinggung angka angka akan tetapi lebih kepada menguraikan, mendeskripsikan, menggevaluasi, dan menyimpulkan tetang peran religiusitas dan batasan waktu audit terhadap efektivitas fungsi audit internal di BMT Karisma, Magelang. Untuk pengumpulan data dalam penelitian ini menggunakan teknik wawancara. Wawancara adalah proses memperoleh keterangan untuk tujuan penelitian dengan cara tanya jawab, sambil bertatap muka antara si penanya atau 


\section{Nominal: Barometer Riset Akuntansi dan Manajemen}

P-ISSN: 2303-2065 E-ISSN: 2502-5430

Volume 9 No 1 (2020)

pewawancara dengan si penjawab atau responden dengan menggunakan alat yang dinamakan interview guide (Nasir, 2009). Penulis menggunakan teknik wawancara dengan tujuan untuk mengumpulkan informasi yang lebih mendalam secara tatap muka, untuk kemudian didapat informasi yang kompleks, lebih mendalam dan berisi pendapat. Narasumber penelitian ini adalah auditor internal BMT Karisma Magelang yang berjumlah 2 orang dan telah menjalani profesi sebagai audit internal lebih dari 5 tahun di BMT Karisma, Magelang.

\section{HASIL PENELITIAN DAN \\ PEMBAHASAN}

\section{Peran Religiusitas terhadap Efektivitas}

\section{Fungsi Audit Internal}

Pertanyaan penelitian pertama yang diajukan adalah untuk mengetahui peran religiusitas terhadap efektivitas fungsi audit Internal. Hasil dari pengumpulan data dengan wawancara menunjukan bahwa religiusitas setiap individu sangat mempengaruhi efektivitas fungsi audit internal yang ditunjukan dengan kehati hatian, ketekunan, dan ketelitian seorang auditor sehingga dapat meningkatkan integritas dan independensi hingga pada akhirnya auditor dapat mencapai keefektivitasan fungsi audit internal.

Religiusitas seseorang tidak hanya dilakukan dalam bentuk ibadah atau ritual yang tampak oleh mata. Namun religiusitas dapat pula dilakukan dalam tingkah laku yang terkadang tidak terlalu diperhatikan oleh orang lain karena aktifitas religius ini terjadi di dalam hati. Sehingga timbul rasa takut untuk menyalahi aturan agama dalam menjalankan tugasnya sebagai seorang internal auditor. Namun dalam kenyataannya, banyak pula faktor yang bertentangan dengan religiusitas yang tentunya dapat mempengaruhi seseorang dan lalai dari aturan agama seperti, faktor ekonomi, psikologis, sosial dan seterusnya yang dapat mengalihkan dari sifat religiusitas sehingga dapat tercipta penyimpangan dari prinsip-prinsip syariah dan menimbulkan terjadinya fraud.

$$
\text { Religiusitas dapat mendorong }
$$
meningkatnya tingkat spiritual sehingga dapat menciptakan rasa bahagia bagi individu dalam menjalankan pekerjaannya. Rasa bahagia ini menjadikan individu lebih nyaman dan produktif dalam bekerja. Begitu pula bagi auditor internal, dengan bekal religiusitas akan menciptakan rasa bahagia saat bekerja sehingga lebih cerdas dalam mencapai efektifitas fungsi audit.

Fungsi auditor Internal di BMT Karisma Magelang adalah sebagai berikut:

a. Mengumpulkan data/ informasi, pencatatan, pengumpulan / klasifikasi, menyimpulkan atas segala transaksi operasional, menerima laporan keuangan 
yang terdiri dari Neraca, Daftar Laba/Rugi, Arus Kas, Perubahan Modal, CAR, Rasio Keuangam serta laporan lain yang diperlukan.

b. Mengumpulkan data/informasi, pencatatan, pengumpulan klasifikasi, menyimpulkan atas segala transaksi dan proses pembiayaan serta membuat laporan yang diperlukan.

c. Memonitor seluruh kegiatan transaksi operasional dan pembiayaan, dan memastikan tidak terjadi penyimpangan atas Standar Operating Prosedure, Memorandum, Surat Keputusan, Surat Edaran, dan Fatwa Dewan Syariah Nasional yang dikeluarkan serta membuat laporan hasil kinerja Pengawasan internal kepada Direktur Utama.

d. Bertanggung jawab langsung dan memberikan internal memorandum kepada Direktur Utama.

e. Bertanggung jawab memberikan informasi dan saran sesuai dengankebutuhan manajemen dan perkembangan baik di bidang operasional maupun pemasaran serta memikirkan cara - cara alternatif yang baik bagi Lembaga.

f. Melaksanakan pemerikasaan pengarsipan bukti - bukti nota debet atau nota kredit, dan lain-lain yang berhubungan dengan seluruh kegiatan transaksi harian.

g. Membuat laporan berkaitan dengan hasil - hasil pemeriksaan secara periodik. h. Melaksanakan pemeriksaan data di lapangan, dicocokan dengan data di dalam untuk menghindari penyelewengan.

i. Menjaga amanah dan nama baik KJKS BMT Karisma dalam menjalankan tugas terutama yang berkaitan dengan pihak luar.

Dengan bekal religiusitas, setiap auditor internal dapat melaksanakan berbagai fungsinya tersebut secara efektif. Sebab religiusitas membawa diri untuk bersikap hati - hati , teliti, dan takut untuk melakukan kesalahan. Religiusitas setiap individu di BMT Karisma selalu dikembangkan melalui kegiatan - kegiatan yang positif, misalnya membaca kitab suci Al Quran (tilawah) bersama setiap Jumat sore, diklat atau pelatihan auditor 3 bulan sekali, hingga tingkat religiusitas dijadikan sebagai persyaratan dan pertimbangan rekruitmen pegawai baru.

Kegiatan positif yang telah diwujudkan seperti membaca Al Quran (tilawah) setiap jumat sore membawa diri untuk selalu mengingat dan takut kepada Tuhan Yang Maha Esa. Kegiatan ini juga dilakukan sebagai ajang untuk memperkuat iman bagi setiap individu agar senantiasa tetap terjaga konsistensi dalam bekerja dengan mewujudkan integritas dan independensi.

Di sisi lain, untuk mewujudkan seorang auditor yang berkompeten dan 


\section{Nominal: Barometer Riset Akuntansi dan Manajemen}

P-ISSN: 2303-2065 E-ISSN: 2502-5430

Volume 9 No 1 (2020)

religius maka diadakan diklat atau pelatihan yang mana dalam kegiatan ini auditor dapat mengupgrade wawasan seputar audit dan mendalami prinsip - prinsip kegiatan atau transaksi syariah. Para auditor internal dapat saling berbagi pengalaman yang pernah dialami seperti ditemukannya fraud dan cara mengatasinya.

Religiusitas dapat mengantarkan individu untuk mewujudkan sikap dan kinerja yang baik. Maka religiusitas menjadi sangat penting ketika digunakan sebagai pertimbangan dalam memilih kandidat kandidat pegawai baru di BMT Karisma. Sebab seseorang yang telah memiliki latar belakang religius yang baik akan mudah untuk dipercaya dan dapat menajalankan pekerjaannya sesuai dengan syariah yang telah diajarkan.

Demi menjaga prinsip - prinsip syariah yang benar dalam pandangan agama, maka sangat diperlukan pula peran Dewan Pengawas Syariah (DPS). Seperti yang tertera dalam Surat Keputusan Dewan Syaiah Nasional (DSN) No.3 Tahun 2000, dijelaskan bahwa Dewan Pengawas Syariah (DPS) adalah bagian dari Lembaga Keuangan Syariah (LKS) yang bersangkutan, dimana penempatannya atas persetujuan DSN. Fungsi DPS adalah sebagai berikut (Abdurrahman Raden Aji Haqqi, 2007):

a. Sebagai penasehat dan pemberi saran kepada direksi, pemimpin unit usaha syariah dan pimpinan kantor cabang syariah mengenai hal - hal yang terkait dengan aspek syariah.

b. Sebagai mediator antara bank dan DSN dalam mengkomunikasikan usul dan saran pengembangan produk dan jasa dari bank yang memerlukan kajian dan fatwa dari DSN

c. Sebagai perwakilan DSN yang ditempatkan pada bank, DPS wajib melaporkan kegiatan usaha serta perkembangan bank syariah yang diawasinya kepada DSN sekurang - kurangnya satu kali dalam satu tahun.

Dengan pengawasan dari DPS ini pula yang menjadikan peran religiusitas dinilai sangat penting karena berpengaruh pada pelaksanaan prinsip - prinsip dan akad syariah serta tercapainya pelaksanaan fungsi audit internal dengan baik. Seperti hal nya auditor, Dewan Pengawas Syariah juga harus bersikap independen.

DPS yang ditugaskan oleh DSN untuk melakukan pengawasan di BMT Karisma, menjalankan tugas pokok dan fungsinya secara rutin setiap satu minggu sekali. Dengan pengawasan rutin ini maka akan selalu terjaga prinsip - prinsip syariah, terciptanya solusi dari masalah yang terajadi, dan memajukan lembaga keuangan syariah. Apabila pengawasan sudah dikasanakan dengan baik maka akan mendorong terciptanya rasa percaya dari masyarakat 


\section{Nominal: Barometer Riset Akuntansi dan Manajemen}

P-ISSN: 2303-2065 E-ISSN: 2502-5430

Volume 9 No 1 (2020)

luas, sehingga dapat menumbuhkan minat nasabah atau pengguna laporan keuangan auditan untuk berpartisipasi menggunakan jasa BMT Karisma. Pengawasan di BMT Karisma ini bukannya hanya dari auditor internal dan DPS saja. Namun juga dilakukan pengawasan dari Auditor Eksternal dalam satu tahun sekali dengan pergantian auditor selama tiga tahun sekali.

Sejalan dengan pemikiran Mihret (2007) dimana efektivitas fungsi audit internal dipengaruhi oleh salah satunya kualitas audit internal, yaitu keahlian staf, lingkup pelayanan, perencanaan audit, pengamatan dan pengendalian serta komunikasi yang efektif. Religiusitas memegang pengaruh kuat dimana sumber daya manusia yang religius membawa diri untuk hati - hati, teliti, dan lebih cermat dalam bekerja. Keahlian staf dapat bercermin pada sikap religiusitasnya. Lingkup pelayanan, perencanaan audit, pengamatan dan pengendalian akan berjalan dengan maksimal jika dibumbui dengan sikap religius. Religiusitas pula yang menjadikan diri untuk lebih peduli dan berempati kepada apapun yang ada di sekitas kita, maka di situlah dapat timbul komunikasi yang efektif karena munculnya rasa ingin tau. Sehingga dapat memaksimalkan kualitas audit internal dengan proses penerapan fungsi audit internal secara efektif.
Religiusitas berperan positif dalam mencapai efektivitas fungsi audit internal, karena atas dasar keyakinan iman dalam hati seseorang akan meminimalisir terjadinya kesalahan dan kecurangan seorang auditor internal dalam menjalankan tugas dan fungsinya. Dengan terwujudnya efektivitas fungsi audit internal melalui faktor religiusitas akan menghasilkan laporan audit yang berkualitas dan dapat dipercaya, serta menjadi langkah untuk memajukan lembaga keuangan syariah.

Peran Batasan Waktu Audit Internal terhadap Efektivitas Fungsi Audit Internal

Pertanyaan penelitian pertama yang diajukan adalah untuk mengetahui peran batasan waktu audit internal terhadap efektivitas fungsi audit internal. Hasil dari pengumpulan data dengan wawancara menunjukan bahwa batasan waktu audit menjadi tantangan seorang auditor untuk mencapai efektivitas fungsi audit. Auditor harus memiliki manajemen waktu di atas batasan waktu yang telah di tentukan sehingga dapat menuntaskan tugasnya tepat waktu dan terhindar dari salah saji.

Audit internal di BMT Karisma Magelang yang merupakan kantor pusat BMT Karisma, hanya memiliki dua individu auditor internal yang harus memeriksa di berbagai cabang BMT Karisma, seperti 


\section{Nominal: Barometer Riset Akuntansi dan Manajemen}

P-ISSN: 2303-2065 E-ISSN: 2502-5430

Volume 9 No 1 (2020)

cabang utama, cabang Grabag, cabang Temanggung, dan cabang Muntilan. Entitas memberikan batasan waktu untuk menjalankan fungsinya dan melaporkan hasil audit satu bulan sekali. Batasan waktu ini yang menjadi tekanan auditor dalam menjalankan fungsinya. Tak hanya batasan waktu yang berpengaruh pada efektif tidaknya pelaksanaan fungsi auditor internal. Namun sumber daya manusia yang hanya terdiri dari dua individu saja dan harus menjalankan fungsi dan tigas nya di berbagai cabang BMT Karisma menimbulkan masalah tersendiri dan menghambat fungsi - fungsi tersebut tuntas secara maksimal.

Disamping menjalankan fungsinya dalam waktu yang telah ditentukan, auditor internal juga berkewajiban menjalankan tugas - tugasnya. Tugas pokok auditor Internal di BMT Karisma Magelang adalah sebagai berikut :

a. Memberikan hasil penilaian mengenai kelayakan dan kecukupan pengendalian di bidang operasional, keuangan, bidang pembiayaan dan kegiatan koperasi lainnya serta peningkatan efisiensi dan efektifitas pengendalian dengan biaya layak.

b. Melakukan pemeriksaan untuk memastikan bahwa semua kebijakan, ketentuan, rencana dan prosedur (yang terutang dalam Surat Edaran, Surat Keputusan, Memorandum dan Standart
Operating Procedure) Lembaga telah benar benar dijalankan dan dipatuhi.

$$
\text { c. Melakukan pemeriksaan }
$$

untuk memastikan bahwa semua harta milik Lembaga telah dipertanggungjawabkan dan dijaga dari semua kegiatan.

d. Melakukan pemeriksaan untuk memastikan bahwa data informasi yang disajikan kepada Manajemen Lembaga dapat dipercaya.

$$
\text { e. Melakukan penilaian }
$$

mengenai kualitas pelaksanaan tugas tiap unit kerja dalam melaksanakan tanggung jawabnya.

f. Memberikan rekomendasi mengenai perbaikan - perbaikan di bidang operasional, pembiayaan dan bidang lainnya. g. Melakukan koordinasi dengan bagian Opersional dan Keuangan dalam hal pengarsipan bukti nota debet/kredit, dan lain-lain yang berhubungan dengan transaksi harian.

h. Membuat laporan yang berkaitan dengan hasil pemeriksaan kegiatan di atas dan menyampaikannya kepada Direktur Utama.

i. Memeriksa semua catatan Lembaga, harta milik dan hutang, memeriksa semua tingkat manajemen (kecuali top management) dan dapat memasuki semua bagian dan unit kerja serta melakukan berbagai Teknik pemeriksaan, 
j. Meminta laporan hasil dari setiap kegiatan yang berhubungan dengan KJKS BMT Karisma.

k. Mencocokkan data yang ada di computer atau program dengan yang ada di anggota (baik yang dating sendiri maupun dibawa kolektor).

Direktur utama memutuskan bahwa auditor internal harus melaporkan hasil kerjanya pada setiap awal bulan. Pelaporan tersebut dipaparkan dalam bentuk tulisan dan lisan. Auditor internal melaporkan dalam bentuk tulisan berupa laporan - laporan yang berisi kumpulan berita acara pemeriksaan di seluruh cabang BMT Karisma. Sedangkan dalam bentuk lisan dengan menyampaikan masalah dan solusi serta rekomendasi oleh auditor internal.

Tantangan waktu bagi auditor ini menimbulkan munculnya perhatian lebih pada fungsi - fungsi audit internal yang dianggap paling penting. Sehingga manajemen waktu auditor benar - benar harus dilaksanakan dengan baik sehingga auditor internal dapat mencapai efektivitas fungsi audit.

Batasan waktu ini juga erat kaitannya dengan religiusitas yang telah dibahas sebelumnya. Tekanan dan keterpaksaan menjadi tiada artinya bagi yang memiliki religiusitas yang tinggi karena semua dapat terkontrol dengan baik melalui iman. Hal ini membuat diri semakin pandai memilah mana yang menjadi prioritas dan mana yang bisa dikerjakan setelahnya. Sehingga dengan dibalut sifat religius dapat meminimalisir pelaksanaan fungsi - fungsi yang dianggap penting saja, namun semua fungsi auditor internal dapat tertuntaskan secara efektif.

\section{SIMPULAN DAN SARAN}

\section{Simpulan}

Berdasarkan pembahasan yang disusun dari hasil wawancara dapat ditarik simpulan bahwa religiusitas individu akan meningakatkan integritas dan independensi auditor yang kemudian dapat mencapai keefektifan fungsi audit internal. Sebab, dengan adanya religiusitas di setiap individu akan mewujudkan kinerja yang penuh kehati - hatian, ketelitian, ketekunan dan terhindar dari kecurangan.

Religiusitas setiap individu di BMT Karisma selalu dikembangkan melalui kegiatan - kegiatan yang positif, misalnya membaca kitab suci Al Quran (tilawah) bersama setiap Jumat sore, diklat atau pelatihan auditor 3 bulan sekali, hingga tingkat religiusitas dijadikan sebagai persyaratan dan pertimbangan rekruitmen pegawai baru.

Dengan pengawasan dari Dewan Pengawas Syariah DPS menjadikan peran religiusitas dinilai sangat penting karena berpengaruh pada pelaksanaan prinsip prinsip dan akad syariah serta tercapainya 
pelaksanaan fungsi audit internal dengan baik.

Dengan terwujudnya efektivitas fungsi audit internal melalui faktor religiusitas akan menghasilkan laporan audit yang berkualitas dan dapat dipercaya, serta menjadi langkah untuk memajukan lembaga keuangan syariah.

Selanjutnya, keterbatasan waktu audit mempengaruhi efektivitas fungsi audit. Batasan waktu audit yang hanya satu bulan menimbulkan tekanan dan tantangan auditor untuk menjalankan manajemen waktu di atas batasan waktu yang telah ditentukan. Sehingga, auditor dapat menuntaskan tugasnya, dan memenuhi fungsi auditor secara efektif.

Tekanan dan keterpaksaan menjadi tiada artinya bagi yang memiliki religiusitas yang tinggi karena semua dapat terkontrol dengan baik melalui iman. Hal ini membuat diri semakin pandai memilah mana yang menjadi prioritas dan mana yang bisa dikerjakan setelahnya.

\section{Keterbatasan Penelitian}

Penelitian ini dilakukan hanya menggunakan instrument penelitian dalam wawancara kepada dua auditor internal. Keterbatasan pada penelitian ini terletak pada subjektifitas dari peneliti dalam menyimpulkan hasil wawancara yang merupakan data primer. Penelitian ini tidak menganalisis langsung laporan audit untuk mendapatkan pengaruh yang lebih kuat dalam pembahasan ini.

Selain itu, keterbatasan tempat penelitian yang hanya meneliti di satu kantor pusat BMT Karisma. Akan lebih kompleks apabila melakukan wawancara mendalam di seluruh cabang BMT Karisma dengan informan yang berbeda supaya dapat mengetahui perbedaan peran religiusitas dan batasan waktu dalam hal ini.

\section{Saran}

Untuk penelitian selanjutnya dapat dilakukan dengan mengembangkan teknik pengumpulan data, tidak hanya dalam bentuk wawancara akan tetapi juga dapat menganalisis langsung laporan audit, serta melakukan cross check data dengan fakta dari informan yang berbeda agar kemudian dapat menganalisa peran religiusitas, batasan waktu audit dan tingkat efektivitas fungsi audit yang lebih kompleks.

\section{DAFTAR PUSTAKA}

Abdurrahman, R. (2007). Shariah Advisory Board in Islamic Financial Institutions In The Eye of Asian Islamic Banks Laws: A Must? (Makalah yang disampaikan pada ASLI Conference, Fakultas Hukum UI), Jakarta.

Eden, D. dan Moriah, L. (1996). Impact of Internal Auditing on Branch Bank Performance: A Field Experiment. 
Organizational Behavior and Human Decision Performance, 68, 262-271.

Hastuti, R, P. (2013). Kualitas Audit, Tekanan Waktu, Locus Of Control, Komitmen Profesional, Perilaku Penurunan Kualitas Audit. Universitas Gajah Mada.

Hendriani, Maria. (2012). Peran UMKM dalam Perekonomian Indonesia.

Kasim, Nawal, et al. (2013). Comparative Analysis on AAOIFI, IFSB, and BNM Shari'ah Governane Guidelines. International Journal of Bussines and Social Science,4(15).

Madjid, R. (1992). Islam Kemoderenan dan Ke-Indonesiaan. Bandung: Mizan Pustaka.

Madjid, N. (1997). Masyarakat Religius. Jakarta: Penerbit Paramadina

Maulina, R., Darwanis, D., dan Saputra, M. (2017). Pengaruh Batasan Waktu Audit, Pengetahuan Akuntansi, dan Auditing, serta Pengalaman terhadap Kualitas Audit (Study Empiris Pada Inspektorat Provinsi Aceh). Jurnal Magister Akuntansi Pasca Sarjana Universitas Syiah Kuala, 6 (2), 59-64.

Mihret., Dessalegn, G., Yismaw, Aderajew, Wondim. (2007). Internal Audit effectiveness: an Ethiopian public sector case study. The Auditor Internal,7(2), 470-484.

Moeller, Robert R. (2005). Brink's modern internal auditing. $6^{\text {th }}$ ed. New Jersey : John Wiley \& Sons, Inc.

Muhammad. (2011). Audit dan Pengawasan Syariah pada Bank Syariah. Yogyakarta: UII Press.
Nasir, M. (2009). Metode Penelitian. Bogor : Ghalia Indonesia.

Pamungkas, I. (2014). Pengaruh religiusitas dan rasionalisasi dalam mencegah dan mendeteksi kecederungan kecurangan akuntansi. Jurnal Ekonomi dan Bisnis, 15(2), 48-59.

Peraturan Menteri Negara Koperasi dan Usaha Kecil dan Menengah Republik Indonesia No.35.3/Per/M.KUKM/X/2007 tentang Pedoman Penilaian Kesehatan Koperasi Jasa Keuangan Syariah dan Unit Usaha Syariah.

Rustiarini, N. W. (2013). Pengaruh Karakteristik Auditor, Opini Audit, Audit Tenure. Jurnal Ilmiah Akuntansi Dan Humanika, 2 (2).

Sahlan, A. (2012). Religiusitas Perguruan Tinggi: Potret Pengembangan Tradisi Keagamaan di Perguruan Tinggi Islam. Malang: UIN Maliki Press (Anggota IKAPI).

Setiawati, R., Parmin. (2019). Pengaruh Religiusitas, Profesionalisme dan Human Capital Terhadap Kinerja Karyawan BMT Al-Amin Gombong dengan Motivasi sebagai Variabel Inervening, Kebumen: Sekolah Tinggi Ilmu Ekonomi Putra Bangsa.

Sumartono., Pasolo, M. R., Nugraha, K. (2019). Study Empiris Kualitas Audit Internal Pemerintah: Melalui Batasan Waktu Audit dan Skeptisme Profesional, Journal of Business Administration 3(2), 245-257.

Svanstrom, T. (2016). Time Pressure, Training Activities and Dysfunctional Auditor Behaviour: Evidence from Small Audit Firms. International Journal of Auditing, 20 (1), 42-51. 
Nominal: Barometer Riset Akuntansi dan Manajemen

P-ISSN: 2303-2065 E-ISSN: 2502-5430

Volume 9 No 1 (2020)

Wirartha, I Made. (2006). Metodologi

Penelitian Sosial Ekonomi.

Yogyakarta: Adi. 